\title{
Changing the message: Employment as a means out of poverty
}

\author{
Kelly Nye-Lengerman* and Derek Nord \\ Research and Training Center on Community Living, Institute on Community Integration, \\ University of Minnesota, Minneapolis, MN, USA
}

Revised/Accepted November 2015

\begin{abstract}
.
BACKGROUND: Poverty is deep-rooted issue that has challenged society throughout history. It is a complex and multilayered problem that requires a reflexive look at inequity across social, cultural, economic, and political spectrums. Poverty does not affect individuals or groups equally. Individuals with disabilities experience poverty at disproportionally higher rates compared to individuals without disabilities. Employment can be an avenue out of poverty for many individuals, yet many individuals with disabilities are not currently employed.

OBJECTIVE: This paper seeks to highlight this problem by continuing a dialogue that draws attention to the significant gaps in poverty rates for individuals with disabilities.

CONCLUSION: Employment is an essential variable to this conversation as the ability to earn a living wage is a central tenant of economic wellbeing and self-sufficiency. It also suggests, we as professionals, use reflexive practices to critically examine personal and professional biases to ensure we are facilitating individuals with disabilities in their pursuit of a working life.
\end{abstract}

Keywords: Poverty, disability, employment, reflexivity

\section{Background}

The United States Census Bureau defines the poverty threshold as the percent of people with earnings in the last 12 months below $\$ 11,945$ for a single person, and below $\$ 23,288$ for a family of four (U.S. Census Bureau, 2013a, 2013b). In the United States today individuals with disabilities experiences poverty at twice the rate of individuals without disabilities (28.4\% versus $12.4 \%$ ), and individuals with cognitive disabilities, which includes intellectual and developmental disabilities (IDD) experience poverty rates three times the national average (34.4\% versus $12.4 \%)$. Poverty rates can vary significantly for these

\footnotetext{
*Address for correspondence: Kelly Nye-Lengerman, Institute on Community Integration, University of Minnesota, 105 Pattee Hall; 150 Pillsbury Dr. SE; Minneapolis, MN 55455, USA. Tel.: +1612 568 7293; Fax: +1 612624 9344; E-mail: knye@umn.edu.
}

groups across states and county levels (Nord, Hamre, \& Nye-Lengerman, 2015; Nord \& Nye-Lengerman, 2015). Combatting poverty requires federal, state, and local interventions. Despite the existence of numerous public and private programs that individuals with disabilities often utilize (Allard, Danzinger, \& Wathen, 2012; Brucker \& Scally, 2015), including Supplemental Security Income (SSI), Social Security Disability Insurance (SSDI), Medicaid waiver programs, Temporary Assistance to Needy Families (TANF), and housing choice vouchers, poverty rates have remained stubbornly consistent over time (Iceland, 2013; Trattner, 2007).

The percent of individuals with and without disabilities looking for work or employed is $28.8 \%$ and $75.8 \%$ respectively. Interestingly, the actual employment rate of individuals with and without disabilities who are living in poverty is nearly equal. In Arkansas 
$52.2 \%$ of individuals with disabilities in poverty are employed compared to $66.8 \%$ of individuals without disabilities living in poverty who are employed. This trend can also be seen in other states such as Colorado $61.9 \%$ versus $75.1 \%$, Maryland $48.8 \%$ versus $67.8 \%$, Wisconsin $57.5 \%$ versus $75.3 \%$ (Nord \& NyeLengerman, 2015). This highlights that despite living in poverty and having a disability many individuals are employed at levels that are unable to elevate them out of poverty.

It is important to recognize that the consequences of poverty also extend beyond income and earnings. Poverty coexists with negative trajectories related to health outcomes, educational access, food and housing security, and social and economic isolation (Gershoff, Aber, Raver, \& Lennon, 2007; Halfon, Larson, Lu, Tullis, \& Russ, 2014; Holzer, Whitmore Schanzenbach, Duncan, \& Ludwig, 2008; McDonough, Sacker, \& Wiggins, 2005). Access to employment can be seen as one of the many solutions to begin to address the consequences of poverty. The ability to earn a living wage with access to healthcare benefits is a necessary component of long-term economic and social well-being. Poverty has additional consequences including social and political isolation, adverse affects on health, and societal economic penalties (Iceland, 2013). These challenges are experienced at both an individual and societal level.

The relationship between poverty and disability is often cyclical. The cycle may start with disability or with the state of poverty itself. Poverty can lead to vulnerability to poor health and in turn disability. A secondary impact cycle may include the denial of social and economic opportunities, deficits in social and cultural rights, reduced participation in decision making and denial of civil rights leading to further social and economic exclusion and isolation (Department for International Development, 2000). Poor physical and psychological health for children and adults can be a contributing factor to poverty, which can also further make employment a greater challenge (Allard et al., 2012; Iceland, 2013).

Employment provides both societal and individual level benefits. Employment can potentially impact an individual's life trajectory. Employment is a means to increase economic self-sufficiency, independence, community participation, and social well being counteracting some of the negative secondary impacts referenced. There is also evidence that suggests individuals with disabilities who are working report a higher quality of life and social engagement (Brucker,
2015; Ra \& Kim, 2016). Being employed provides the ability to purchase goods and services, which are also drivers of economic growth.

Addressing employment is critical, but even workers with disabilities are experiencing poverty at higher rates despite education and training. Yin, Shaewitz, and Megra (2014) found that workers with disabilities are paid .64 cents to every dollar as compared to workers without disabilities, and the inequity is greatest for those with advanced degrees. In addition Mann and Wittenburg (2015) report that evidence for employment and wages differences of individuals with disabilities emerge by age 24 and may be linked to disparities later in life. Therefore addressing employment is only part of the equation. We also have to explore how poverty and biases play a role in perpetuating these imbalances.

Additionally many individuals with cognitive disabilities do not have the opportunity to participate in integrated employment. Robust service systems, often in the form of Community Rehabilitation Providers (CRPs), have been developed over time to create employment opportunities for individuals with disabilities. While well intended at inception, today these types of segregated employment programs systematically keep individuals with disabilities from accessing competitive, integrated employment (National Disability Rights Network, 2011). As of November 1, 2013, 3,317 programs, including 2,744 CRPs, carry certifications from the Department of Labor, which allow them to pay workers with disabilities below the minimum wage (State Employment Leadership Network, 2015). These certificates are issued under section 14(c) of the Fair Labor Standards Act of 1938 to vendors who provide employment services to individuals with disabilities and are referred to as 14(c), sub-minimum wage, or commensurate wage certificates. Many individuals with disabilities working in segregated settings do not have the opportunity to earn the minimum or a living wage. Many national organizations such as Association of People Supporting Employment First (ASPE), Self Advocates Becoming Empowered (SABE), the National Disability Rights Network (NDRN), and TASH have called for the repeal of section 14(c) of the Fair Labor Standards Act. However, there are many organizations whose business models relay heavily on sub-minimum wage compensation to workers with disabilities. The payment of sub-minimum wage to workers with disabilities further contributes to this population living in poverty without the ability to making a living wage. 


\section{Value of reflexivity in practice}

Reflexivity is defined as a circular process of bidirectional evaluation or analysis. In the social sciences, the act of being reflexive means having the ability to look or "bend back on" oneself for review or examination (Finlay \& Gough, 2008). The ability to be reflexive and examine our own habits, beliefs, values, and practices can be seen valuable tool to recognize biases, barriers, and professional blind spots that may influence how our practice is provided. These barriers and biases are not necessarily to be viewed as negative components of our personal and professional selves, rather the value is the awareness and recognition of them and how they may influence how we practice or provide supports. "I need to be always aware of my privileged standpoint when doing research with those more oppressed so that I don't (un)wittingly abuse my power to shape representations and interpretations of lived experience" (Diversi \& Finley, 2010, p. 15).

Many professionals in human services and academia have the luxury of admiring and wrestling with the issues of poverty as spectators. It is not uncommon to hear messages about individuals with disabilities that include "He should be grateful for what he gets." "She will never be able to earn that much." "They basically live a middle class lifestyle." We make assumptions about the capabilities of individuals with disabilities and in some cases what we they want in their lives. These messages spoken and unspoken contribute to additional oppression experienced by individuals with disabilities and may prevent critical professional and cultural movement towards solution-focused responses.

As professionals we may, in fact, be one of the most significant barriers to developing more creative and empowering solutions to these complex challenges. Reflexively examining our personal and professional biases can be an essential step in recognizing that many professionals themselves are benefiting from those experiencing poverty. For professionals in the industry beginning with difficult core questions around ability, worthiness, and poverty can be first steps in critical self-examination. Why can't an individual with a significant cognitive disability work independently in the community? Why are individuals who receive multiple public benefits a drain on our system? Why do I think only individuals with disabilities should be paid based on arbitrary productivity when no other group is held to the same standard? Through careful examination of answers to these and other difficult questions can lay our subcon- scious messaging that we inadvertently project on to individuals with disabilities or their families. Recognition and awareness of our biases is necessary to address how they may affect this work.

\section{Recommendations}

Equal and fair earnings are essential to ensure that individuals with disabilities can move out of poverty. The elimination of 14(c) certificates is necessary to guarantee that individuals with disabilities have access to fair wages. Ongoing federal and state initiatives and litigation is drawing more attention to how sub-minimum wage discriminates against workers with disabilities and contributes to economic oppression. Integrated competitive employment for workers with disabilities can be within reach with the elimination of sub-minimum wage.

The use of empowering language that facilitates and supports employment rather than protecting benefits is crucial. Understanding the relationships between public programs such as Medicaid, SSI, and SSDI is important to be able to provide individuals, families, and professionals accurate information. Poverty does not have to be a sentence required over a lifetime, because employment can be a reality for individuals with disabilities. Benefit counseling is a critical ingredient to understanding the relationship between work and benefits. There are a number of strategies and programs that support the movement of individuals off or away from public benefits that include benefits counseling including: Ticket to Work (TTW), Plan to Achieve Self Support (PASS), Promoting readiness of minors in supplemental security income (PROMISE). Scaffolding or braiding supports for an individual and or family is an important strategy for long-term success (Hall, Butterworth, Winsor, Gilmore, \& Metzel, 2007; Nord, Lueking, Mank, Kiernan, \& Wray, 2013).

Poverty is a multifaceted problem and that it touches many areas of an individual's life beyond employment including housing, education, inclusion, and self-determination. Investments must be made holistically looking at the whole person and should go beyond just the economic benefits to include social, emotional, and cognitive benefits. A working life is a reality for individuals with disabilities, but the recognition of how these facets affect an individual's ability to maintain employment is necessary. Strategies to combat poverty come in many forms: social, cultural, and economic (Trattner, 2007). Limiting the 
strategies to only one area reduces the possibility of creating long-term solutions.

Supports and services should be focused on ending poverty rather than perpetuating it. Early investment is critical to combat poverty and raise the expectations of employment. The expectations of parents and teachers are some of best predictors of employment participation and success for youth with disabilities (Holwerda, Brouwer, de Boer, Groothoff, \& van der Klink, 2015; Wehman et al., 2015). According to economist James Heckman (2015), "While inequality could be addressed with direct transfers of money to disadvantaged individuals and families, unconditional transfers are not as effective as programs that provide early resources for developing skills in children that increase productivity and earnings in the adult years" (p.1). Early and ongoing education and investment is key to breaking the cycle of poverty through the promotion and expectation of employment.

Thoughtful and ongoing reflexivity at various points in time provide a more in depth understanding and context for the work we do to support the full employment of individuals with disabilities. Until we, as a field, begin to uncover and acknowledge the personal and professional biases that influence our work, meaningful opportunities for empowerment and engagement of individuals with disabilities will remain elusive. Collectively these biases contribute both directly and indirectly to the low employment rates of individuals with disabilities and perpetuation of their lives in poverty.

\section{Conflict of interest}

None to declare.

\section{References}

Allard, S., Danzinger, S., \& Wathen, M. (2012). Receipt of public benefits and private support amount low-income households with children after the great recession. Policy Brief, 12, Ann Arbor, MI: National Poverty Center.

Brucker, D. L. (2015). Social capital, employment and labor force participation among persons with disabilities. Journal of Vocational Rehabilitation, 43(1), 17-31. doi: 10.3233/JVR150751

Brucker, D., \& Scally, C. (2015). Linking public housing, employment, and disability benefits for working-age people with disabilities. Housing and Society, 42(2), 126-147.
Bureau of Labor Statistics (2015). Table A-6. Employment status of the civilian population by sex, age, and disability status, not seasonally adjusted. Retrieved from http://www.bls.gov/news. release/empsit.t06.htm

Department for International Development (2000). Disability, poverty, and development. Retrieved from http://hpod.org/pdf/ Disability-poverty-and-development.pdf

Diversi, M., \& Finley, S. (2010). Poverty pimps in the academy: A dialogue about subjectivity, reflexivity, and power in decolonizing production of knowledge. Cultural Studies Critical Methodologies, 10(1), 14-17. doi: 10.1177/1532708609 351147

Erickson, W., Lee, C., von Schrader, S. (2014). Disability Statistics from the 2012 American Community Survey (ACS). Ithaca, NY: Cornell University Employment and Disability Institute (EDI). Retrieved from www.disabilitystatistics.org

Finlay, L., \& Gough, B. (Eds.). (2008). Reflexivity: A practical guide for researchers in health and social sciences. Hoboken, NJ: John Wiley \& Sons.

Gershoff, E. T., Aber, J. L., Raver, C. C., \& Lennon, M. C. (2007). Income is not enough Incorporating material hardship into models of income associations with parenting and child development. Child Development, 78(1), 70-95.

Halfon, N., Larson, K., Lu, M., Tullis, E., \& Russ, S. (2014). Lifecourse health development: Past, present and future. Maternal and Child Health Journal, 18(2), 344-365. doi: 10.1007/s10995-013-1346-2

Hall, A. C., Butterworth, J., Winsor, J., Gilmore, D., \& Metzel, D. (2007). Pushing the employment agenda: Case study research of high performing states in integrated employment. Intellectual and Developmental Disabilities, 45(3), 182-198. doi: 10.1352/1934-9556(2007)45[182:PTEACS]2.0.CO;2

Heckman, J. (2015) Building a scaffolding of support: A comprehensive approach to human capital development pays off. Retrieved from http://heckmanequation.org/content/resource/ build-scaffolding-support- 0

Holzer, H. J., Whitmore Schanzenbach, D., Duncan, G. J., \& Ludwig, J. (2008). The economic costs of childhood poverty in the United States. Journal of Children and Poverty, 14(1), 41-61.

Holwerda, A., Brouwer, S., de Boer, M. R., Groothoff, J. W., \& van der Klink, J. J. (2015). Expectations from different perspectives on future work outcome of young adults with intellectual and developmental disabilities. Journal of Occupational Rehabilitation, 25(1), 96-104.

Iceland, J. (2013). Poverty in America: A handbook. Berkley, CA: University of California Press.

Mann, D. R., \& Wittenburg, D. C. (2015). Starting behind wage and employment differentials between young adults with and without disabilities. Journal of Disability Policy Studies, 26(2), 89-99. doi: 1044207315583898

McDonough, P., Sacker, A., \& Wiggins, R. D. (2005). Time on my side? Life course trajectories of poverty and health. Social Science \& Medicine, 61(8), 1795-1808.

National Disability Rights Network (2011). Segregated and exploited: A call to action. Retrieved from http://www.ndrn. org/images/Documents/Resources/Publications/Reports/Segre gated-and-Exploited.pdf

Nord, D., Hamre, K., \& Nye-Lengerman, K. (2014). Understanding community poverty, housing and disability. Policy Research Brief, 24(3), Minneapolis, MN: University of Minnesota. 
Nord, D., Luecking, R., Mank, D., Kiernan, W., \& Wray, C. (2013). The state of the science of employment and economic self-sufficiency for people with intellectual and developmental disabilities. Intellectual and Developmental Disabilities, 51(5), 376-384. doi: 10.1352/1934-9556-51.5.376

Nord, D., \& Nye-Lengerman, K. (2015). Employment for people with disabilities in poverty: A need for national attention. Policy Research Brief, 25(1), Minneapolis, MN: Research and Training Center on Community Living at the University of Minnesota.

Ra, Y. A., \& Kim, W. H. (2016). Impact of employment and age on quality of life of individuals with disabilities: A multilevel analysis. Rehabilitation Counseling Bulletin, 59(2), 112-120. doi: 0034355215573538

State Employment Leadership Network (SELN) (2015). Number of certificates held by community rehabilitation programs. Boston, MA: Institute for Community Inclusion, University of Massachusetts Boston.
Trattner, W. I. (2007). From poor law to welfare state: A history of social welfare in America. New York: Simon and Schuster.

U.S. Census Bureau (2013a). How the Census Bureau measures poverty. Retrieved from https://www.census.gov/hhes/www/ poverty/about/overview/measure.html

U.S. Census Bureau (2013b). Table B23024: Poverty status in the past 12 months by disability status by employment status for the population 20-64 years, 2008-2012 American Coтmunity Survey 5-year estimates. Retrieved from http://factfinder. census.gov/faces/nav/jsf/pages/index.xhtml

Wehman, P., Sima, A. P., Ketchum, J., West, M. D., Chan, F., \& Luecking, R. (2015). Predictors of Successful Transition from School to Employment for Youth with Disabilities. Journal of Occupational Rehabilitation, 25(2), 323-334. doi: 10.1007/s10926-014-9541-6

Yin, M., Shaewitz, D., \& Megra, M. (2014). An uneven playing field: The lack of equal pay for people with disabilities. Washington, D.C.: American Institutes for Research. 